\title{
Osmanlı Kanunnamelerinde Islâm Ceza Hukukuna aykırı hükümler
}

\author{
Doç. Dr. Coşkun Ùđ̧ok
}

GIRİS: 3. Kasım 1839 (26. Şaban 1255) tarihli Hattı Humayun'un Mustafa Reşit Paşa tarafından Gülhane'de okunmasının üzerinden tam altı ay geçtikte Tanzimat'in ilânından sonra çıkarılan kanunlarin ilki olan 3 Mayıs 1840 (1. Rebi I. 1256) tarihli "Kanun-i Ceza" çıkarılmıştı (1). Bir mukaddime on üç fasıl ve bir hatimeden (2) ibaret olan bu kanun, esas itibariyle İslâm hukukundan pek ayrılmazsa da İslâm hukukunda bulunmıyan birçok yenilikleri de içine almaktadır. Islâm hukukuna pek aykırı olmamakla beraber Tanzimat'dan sonra' çıkarılmış olan ilk kanunun bir ceza kanunu olması bir tesadüf eseri değildir; zira daha önceleri Fatih Sultan Mehmed, Kanunî Sultan Süleyman ve diğer hükümdarlar zamanlarında çıkarilmis olan kanunnamelerde de kismen olsun İslâm ceza hukukundan ayrılmak yolu tutulmuştur. Gerçek İslâm Devleti, İslâm'ın çıktığı VII. yüzyllda ve onu kovuşturan yüzyıllarda başdöndürücü bir sür'atle genislemeğe başlayınca Kuran'ın ve Sünnet'in tespit etmiş oldugu hukuk kuralları bu büyük devletin ve onu teşkil eden büÿ̈jk insan topluluklarınin bütün ihtiyaclarını karşllyamaz bir duruma girmis. bunun icin de bir vanctan Kivas ve tema yoluyla İslâm hukukunun boslukları doldurulmıya çalışılmış, öbür yandan da ister istemez yerli örf ve âdet hukukuna yer verilmiștir. Bir çok noktalarda çok ileri düșüncelere dayanan İslâm ceza hukukunư da bazı suçlara tâỵin etmiș olduğu cezalarm çok ağır olması ve bazı suçluların cezalandırnlması için koştuğu şartların o suçlụların neticede az bir ceza ile kurtulınalarmı sağlaması, iç hayatlarını düzenlemek istiyen

(1) 'Bk. Ahmed Lûtfi, Mir'at-i Adalet, s. 127 v. öt.

(2) Türk Tarih Kurumundaki yazma nüsshada (No. 10) hatime yerine 3 madđlelik bir *Zeyl-i 14. fasıl» vardır ki kalpazanilk ve evrak sahtekârlığından bahsetmektedir. 
birçok İslâm devletlerini, daha çok erken bir zamanda türlü noktalardan İslâm ceza hukukunu terketmek ve ya onun hükümlerini yeni kurallarla tamamlamak zorunda birakmıştır; öyle ki 20. yüzyıllm ilk on yıllarında, İslâm dỉnini her yönde ayniyla uygulamaya çalışan Sâudi Arabistan bir yana bırakzlırsa İslâm ülkelerinin çoğunda İslâm ceza hukuku ya kısmen ya tamamen bırakılmış bulunuyordu. Daha önceleri Fatih Sultan Mehmed gibi henüz Halife olm1yan ve Kanunî Sultan Süleyman gibi üstelik Halife de olan Osmanlı Padişahları da İslâm ceza hukukuna aykırı hükümleri, çıkartmış oldukları kanunnamelere koymaktan çekinmemişlerdi.

İşte bu yazımızda türlü padişahlar zamanında çıkarılmıs olan kanünnamelerin bazılarında İslâm ceza hukukuna aykırı ne gibi hükümler bulunduğunu, ne gibi hususlar için ne gibi yeni hükümler konulmuş olduğunu tespit etmek istiyoruz. Bunun için önce İslâm ceza hukukuna toplu olarak bakmayı faydalı buluvoruz. Bu suretle hem Arap harflerini bilmiyen veya yabancı bir dil anlamiyan arkadașlarımıza İslâm ceza hukuku hakkında toplu bilgi vermek imkânınt elde etmiş, hem de Osmanlı kanunnamelerindeki hükü̈mlerin ne gibi hususlarda İslâm ceza hukukundan ayrıldıklarını daha iyice göstermek firsatını bulmuş oluruz.

Osmanlı kanunnamelerinden incelemek üzere seçtiklerimiz şunlardir:

1) Fatih Sultan Mehmed Kanunnamesi (MOG, I. 1921, S. 19 ve öt.).

2) Kanunî Sultan Süleyman Kanunnamesi (TOEM, 16 - 19. saylara ek).

3) Bosna Kanunnamesi (Glasnik Zemaliskog Muzeja u Bosni i Hercegovini, XXXVIII, 1916, 3/4 S. 448 ve öt.).

4) IV Mehmed zamaninda (1648 - 1687) yürürlükte olan ceza. kanunnamesi (Ahmed Lûtfi, Mir'at-i Adalet, S. 78 ve öt.).

I. - ISLÂM CEZA HUKUKU: İslâm'da ceza hukukuna "Ukubat" denir. İslâm dinine göre hayatta insanların işledikleri eylemler ceza hukuku bakımından yediye ayrilır:

1) Furz olan eylemler: Bunlar öyle eylemlerdir ki Allah'm bunların yapımasını emrettiği hakkında ayetler ve mütevatir, sarih hâdisler vardur: Msl. namaz kılmak, oruç tutmak, zekât vermek gibi. Bunların yapılması gerektiğine inanmıyanlar kâfir sayilırlar. Bu eylemleri yapmıyanlar ise öbür dünyada belli cezalara çarptirılırlar. 
2 Vacib olan eylemler: Bu gibi eylemlerin yapimasını da Allah'ın emrettiği hakkında ayetler ve müevvel hâdisler vardır. Msl. Şeker bayrammda sadaka vermek veya Kurban bayrammda kurban kesmek gibi. Bu gibi tylemleri yapmlyanlar da öbür dünyada cezalandurlirlarsa da bu eylemlerin vacip olmadığına inananlar kâfir sayılmazlar.

3) Sünnet olan eylemler: Bunlar Peygamber'in çokça yapmış olduğu eylemlerdir: Msl. toplu olarak ibadet gibi. Bu gibi eylemleri yapmiyanlar azarlanirlar ve öbür dünyada cezalandurılmazlarsa da Peygamber'in şefaatine de güvenemezler.

4) Mustahab (veya nafl veya mandûb) eylemler: Bunlar Peygamber'in arasıra yaptığı veya bu eylemleri yapan kimselere bunların mükâfatlandırılacaklarını söylediği eylemlerdir. Msl. farz olmiyan ibadetler ve sadakalar. Bu eylemleri işliyenler sevap kazanirlar, işlemiyenler azarlanmazlar

5) Mubah olan eylemler: Bunlar öyle eylemlerdir ki yapılmalar mükâfatlandırılmadığı gibi yapılmamaları da günah sayılma:z Msl. konuşmak, uyumak, yürümek gibi.

6) Haram olan eylemler: Bunlar Allah'ın kesin olarak menettitiği elyemlerdir: Msl. zịna işlemek ,adam .öldürmek vsr. gibi. Haram bir eylemi yapan ve yaptığına pişman olmıyan kimseler öbür dünyada cezalandırıldığı gibi bazı durumlarda pişmán olsun veya olmasin bu dünyada da cezalandırılırlar. Haram bir eylemin haram olmadığını söyliyenler ise kâfir saylurlar.

7) Mekruh olan eylemler: Buntar öyle eylemlerdir ki bunlar1 işliyenlerin öbür dünyada ceza görmesinden korkulur ve islemiyenler sevap kazanir: Msl. uygunsuz bir zaman veya yerde ibadet etmek, camide sadaka vermek gibi (3).

Işte Islâm ceza hukuku bu eylemlerin haram olanları ile uğraşir. $\mathrm{Bu}$ gibi eylemlerin işlenmessine engeller koymaya çalıșır; işliyenleri ise cezalandirrr.

İslâm ülkesinde yani İslâm hukukunun, İslâm kanunlarının uygulanabildiği yerlerde yașıyan ve yaşamak istiyen Müslüman ve Ehl-i Kitap kimselerin (Zimmî olsun Müste'min olsun) hayatı, malı, ırzı ve serefi İslâm ceza bukuku tarafından eşit olarak korunur. Bunlara dokunanlar ise ayn hukuka uyularak cezalandırılır. Hürler gibì

(3) Eylemlerin taksimi hakkında fazla bilgi için Bk. Mehmet $\cdot$ Zihni, Kitab-ïl-Tahare, 5.4 v. öt. orada eylemler sekize ayrilmaktadir. 
kullar da İslâm ceza hukuku tarafindan korunurlar, yalnız bazı durumlarda gerek kula karşı işlenen suçlara gerek kullarm işlediği suçlara daha hafif cezalar verilir. Müslüman olsun Zimmî veya Müste'min olsun bir kimsenin cezalandrrlabilmesi için ise o kimsenin ergin (baliğ) olması gerekir. Erginlik alâmetleri kendisinde gözüken erkek ve kadınlara ergin denir, ancak kızlar 9 uncu erkekler 12 inci yaşlarmdan önce ergin sayllamazlar. 15 inei yaşlarmı geçirmiş olan kızlar ve erkekler ise erginlik alâmetleri kendilerinde görülmese bile ergin sayllirlar.

Bir kimsenin cezaya çarptırlabilmesi için ayrıca aklı başında olması gerekir. tradesini sarhoşluk gibi bir sebeple geçici bir zaman için kaybetmiş olanlar bu durumda işledikleri suçlardan ötürü sorumlu saylihlar.

İslậm Ceza hukukuna göre cezalandırılması gereken "Haram» eylemler başlıca şu şekilde sıralandırılabilirler:

İnsanm "akl" una karşı işlemiş olduğu eylemler. Mssl. sarhoş edici içki içmek ve sarhoșluk gibi.

Neseb'e karşı işlenmiş eylemler; zina gibi.

Başka birisinin malma karşı işlenmiş olan eylemler. Msl. hırsızhk ve yol kesme gibi.

Başkasmin Irz ve şerefine karş̧ı işlenmiş olan eylemler; zina iftirası (Kazf) gibi.

Başkasının canma veya vücut sağlığına karşı işlenmiş olan eylemler; öldirrme ve yaralama gibi.

Dar-ül-İslâm'da oturanların genel olarak rahat ve barış içinde yaşamalarına karşı işienmiş olan eylemler; yalan yere tanıklık, küfür, dövme vsr. gibi.

Suç işìyen kimselerin cezalandırılmasını istemek hakkı İslâm ceza hukukuna göre ya Allah'a (Hakk Allah) ya zarar gören kişiye veya varislerine aittir (Hakk-i Âdemî). Bu yarım bir bakıma bugünkü modern ceza hukukundaki "Resen kovuşturma" "şikâyete bağlı kovusturma" ayrımına benzemekte ise de her noktada bu ayrımlar birbirine uymazlar. Fakk Allah'a giren suçları kovuşturmak ve faillerini cezalandırmak genel olarak İslâm devletinin reisine veya onun tâyin etmiş olduğu yargıca aittir; Hakk-i Âdemíye giren bir suçun kovuşturulmasını ve cezalandırılmasını isternek hakkı ise zarar gören tarafa veya mirasçlarına düşer, Ne Haǩk-i Âdemîye ne de Hakk Allah'a giren suçları işlemiş olan kimseleri affetmek hakkı devlet reisine verilmemiştir. Çünkü birisi insanın mamelek hukuku 
çerçevesine diğeri ise tanrı hukuku çerçevesine girmektedir. İșlâm devleti reisinin ise ne biri ne diğeri üzerinde tasarrufa hakk yoktur.

İşlenen suçlar ya Hakk Allah'ı yahut da Hakk-i Âdemî'yi ihlâl edebileceği gibi her ikisini de ihlâl etmiş olabilir; buna göre fıkıhçılar suçları șu șekilde taksim ederler:

1) Yalnız. Hakk Allah'a giren suçlar. Bunlar Islâm camiasmmn menfaatlerine dokunan suçlardır, zina işlemek, şarap içmek, sarhoş olmak ve yol kesme gibi. Bu gibi suçları işliyenlerin cezalandımlmas1 için zarar görmüş olan yanin şikâyeti gerekmez, zira bu suçlarm işlenmesi ile Allah yanından, insanların bir aradà yaşamaları için. kurulmuş olan dïzen bozulmuş ve böylece Allah'a karşı gelinmiştir. Allah kendisi böyle suçların cezalandırılmasını istiyemiyeceği için bu gibi suçları kovuşturmak vazifesi Devlet reisine veya onun yargicina düşer, ve her iyi Müslüman'm böyle suçları haber vermek vazifesidir. Ancak gene Allah böylece hakkını arıyamadığı içindir ki yukardaki suçlardan biri ile sanık bulunan kimse duruşma sırasındaki ikrarını geri alabilir ve zamanaşımi ile dava düşer. Buna rağmen bu gibi suçlardan zarar görenler de davaya karışbilirler ve yargı̣ işlenen suçtan haberdar edilmeden önce suçluyu affederek cezadan kurtarabilirler.

2) Yalnız hakk-i Âdemi'ye giren suçlar. Bunların işlenmesi ile yalnız tek tek fertlerin menfaatleri ihlâl edilmiş olur, Bu gibi suçluların kovuşturulması için zarar gören kimsenin şikâyeti şarttır.

3) Hem Hakk Allah'a hem de Hakk-i Âdemi'ye giren suçlar. Bunlar da iki kısma ayrilurlar:

a) Daha çok Hakk Allah'ı ihlâl etmiş olmakla beraber Hakk-i Âdemiłyi de ihlâl etmiş olan suçlar. Msl. zina iftirasi (= Kazf) gibi. $\mathrm{Bu}$ suçu işliyen kimsenin kovuşturulması için zarar gören yanın şikâyeti gerekir. Suçunı jkrar eden suçlu ikrarmı geri alamaz, çünkü ikrar ile zarar gören yanın elde etmiş olduğu hakları suçlu bị yanlı olarak ortadan kaldıramaz ve duruşmada zamanaşımı ileri sürülemez.

b) Daha çok Hakk-i Âdemi'yi ihlâl etmiş olmakla beraber Hakk Allah'ı da ihlâl etmiş olan suçlar. MsI. Kısas'a uyruk olan suçlar gibi. Burada verilen Kısas cezası da ilâhi bir karakter taşımakla beraber ceza verilmesini istemek zarar görenin hakkıdır ve bu ceza mahî cezaya da dönerek miras konusu da olabilir. Bundan ötürü de bu gibi suçların kovuşturulabilmesi için zarar gören yanın şikâyeti şarttır. Zarar gören kimsesizse ve ölmüşse o zaman malları Beyt üI - 
Male kalacağından bu gibi durumlarda suçlunun cezalandırlmasın istemek hakkı da İslâm. Devleti reisine verilmiş̧ir (5).

İslâm ülkesinde oturanların genel olarak rahat ve barış içinde yaşamalarına karşı işlenmiş olan suçlar da kovuşturma bakımından Hakk-i Âdemi'ye girerlerse de birçok sebeplerle Hakk Allah'ı da ihlâl etmiş olabilirler.

Haram olan eylemlere uygulanması gereken cezalara gelince, bunlar ya Kur'an, Sünnet veya Icma-i Ümmet ile tespit edilmişlerdir ve değişmezler (Ukube-i Mukaddere) veya bunlarm tâyini İslâm devleti reisine veya onun yanindan konulmuş olup onun yerine yarg1 işlerine bakan yargıçlara bırakılmıştır (Tazir). Bunlar suçlunun durumuna, suçun işleniş şekline göre değişebildiği halde birinciler hiç bir suretle değişmezler, yani birinciler de cezaları çoğaltıcı veya azaltıcı şahsî veya takdirî sebeplere yer verilmemiştir. Suçlu ya belli olan cezaya çarptırlır veya beraet eder.

Verilen cezalar bakımından ise şu iaksim yapılabilir: 1) Hakk Allah'a giren belli ve değişmez cezalar; bunlar zina, zina iftirası, şarap içme, sarhoşluk, hrrsızlık ve yol kesmeden ötürü verilen cezalar (Hadd) dan ibarettir. 2) Hakk-i Âdemî̀ye giren belli ve değgşmez cezalar; bunlar ise kisas ve Diyet'dir.

Değişmez (Hadd, Kısas, Diyet) olsun değişir (Ta'zir) olsun cezalar şunlardan ibarettir:

Suçlunun suçu iş̧emiş olduğunu yüzüne karşı söylemek.

Suçluyu yalnızca azarlamak, veya kulağını çekmek, teşhir etmek vsr. ile birlikte azarlamak.

Malî cezalar.

Sürgün.

Hapis.

Sopa dayağı.

EI, ayak veya her ikisini birden kesme.

İdam (kılıçla, taşlayarak veya salbederek).

Mirastan mahrumiyet.

Ergin ve aklı başında olmak şartiyle İslâm ülkesinde oturan herkesin işlediği suçun cezasını çekmek mecburiyetinde olduğunu söylemiștik. Bu kuralın hiçbir istisnası yoktur. İslâm devleti reisi de işlediği suçların cezasını çeker, yalnız Hakk Allah'ı ihlâl eden suçlardan ötürü İslâm Devleti reisi cezaya çarptırılmaz. Zira bu gibi

(4) Bk. Krcsmarik, bibliyografiyada adı geçen eser $\$ .91$ v. öt.

(5) Bk. 1267 tarihli ceza kanunu I. Fasil 12. madde. 
suçları işliyenleri cezalandrrmak Devlet Reisi'nin vazifesidir, halbuki hiç kimse bir cezayı kendi kendine uygulayamaz.

İslâm ceza hukukunda "Herkes işlediği suçun cezasmı kendisi çekecektir» ileri ilkesi kabul edilmiş, yani ceza şahșileştirilmiş olmakla beraber bu ilkenin tam uygulanmadığı durumlar da vardır. Msl. öldüren bulunmadığı hallerde ölünün bulunduğu yerde ve oraya belli bir yakınlıkta oturan ergin erkeklerin bu suçtan ötürü sorumlu saylmaları (Kasame), veya bilmiyerek ve istemiyerek bir kimseyi öIdürenlerin vermesi gereken Diyet'i suçlunun "Âkile" denilen erkek kan hısımlarının veya mevlâlarınun ödemesi gibi.

Bir kimsenin bir cezaya çarptırılması için ergin ve akI başında olması yetmez o suçu bilerek ve istiyerek işlemiş olması ve diştan gelen bir basınçla işlememiş olması gerekir. Sanığın suçu işlemiş olduğu ya sanığın ikrarı ile veya tanıklarla sabit olur. Bazı fıkıhçılara göre bir suçun ispat edilebilmesi için kaç tanık gerekiyorsa sanığm da ancak o kadar defa suçunu ikrar etmesinđen sonra suçu işlemiş olduğu sabit olur.

Hakk Allah'ın ihlâl edilmiş olmasından ötürü ceza verilebilmesi için yalnız erkekler tanıklıkta bulunabilirler, çünkü kadınlar içtimaî durumlar dolayısiyla bu gibi olaylar hakkında doğru bilgi edinemezler.

Tanıklar tanklıkta bulunmıya mecbur değildir, isterlerse söylerler isterlerse susarlar.

Islâm hukukuinda "Takadüm-i zaman ile hak sakıt olmaz" (6) ilkesine karşıllk "Takadüm-i zaman ile Hadd sakıt olur» (7) ilkesi yer almıştır. Yani zamanaşımına uğramış olan suçlara Hadd cezası verilmez, zira zamanaşımı bulunan meseleler hakkında yargıc tanık dinliyemiyeceği gibi verilmiş olan cezaları da.uygulryamaz. Takadüm-i zaman ile hak sakıt olmadı̆̆ için ise suçu işliyen suçunu ikrar ederse cezasın c çekmesi gerekir; ancak ikinci ilkeye uyularak bu gibi durumlarda yargıç, şikâyetçinin şikâyetini ve tanıkları dinlemekten menedilmiştir. Zamanaşımının süresi suçlara göre değişmektedir ve bu hususta fıkıhçlar birbirinden ayrılmaktadırlar. Hakk Allah'a karşı işlenen suçlarda zamanaşımı bazılarına göre bir ay bazllarına göre ise altı aydır. Şarap içmeden ötürü verilecek olan ceza, içenin ağzında șarap kokusu kalmaymnca zamanaşımına uğramış olur ve artık suçlu suçunu ikrar da etse cezalandırılmaz. Zira iftirası ise zamanaşımına uyruk değildir.

(6) Bk. Mecelle. Md. 1674.

(7) Bk. Mevkufat, I, 361 . 
Hakk-i Âdemî'yi ihlâl eden suçlar da zamanaşımına uyrukdurlar. Ancak burada verilen cezalar netice itibariyle mamelek haklar1n ilgilendirdiği için özel hukukta bu hususta kabul edilmiş olan zamanaşımı süreleri burada da uygulanır.

K.ısas dışında verilen cezaları uygulamak İslâm Devleti reisinin. ödevidir; Devlet reisi isterse bu ödevini tâyin etniș olduğu yargıçlar aracıyla da yerine getirebilir. Ancak bazı durumlarda özel kişiler de, kendileri bir cezaya çarptırılmaksızın başkalarına karşı cebir kullanabilirler. Zira her Müslümanın suç işlemekte olan bir kimseyi bundan menetmesi vazifesidir. Bunun için haram bir eylemi işlemekte olan bir kimseyi gören bir Müslüman kuvvet kullanarak onu bu işten vazgeçirtebilir ve bunu yapmış olduğu için cezalandırılmaz. Bir kimsenin kendi nefsine karşı olan bir hücumu da kuvvet ve cebirle savması da tabiidir ki cezalandırılmaz. Baba, cocuklarını; koca, karısını; efendi. kullarını ve öğretmen, öğrencilerini cezalandırabilirler. Ancak burada belli sunrlar çizilmiştir, bu sumrları aşanlar da işledikleri eylemlerden ötürü sorumludurlar: Msl. baba, çocuğunu veya efendi, kulunu yaralıyamaz. Buna karş̧ılık zina işlerken karısını yakalıyan koca ve malını çalarken hırsızı yakahyan mal sahibi için bu suçluları cezalandırma bakımından bir sınır konulmamıștır. Bir de Kısas'a uyruk olan suçlarda yargıcın uygulanmasına hüküm verdiği cezaları zarar gören yan isterse kendi uygulayabilir.

Genel olarak İslâm Ceza hukuku hakkında bunları gördükten sonra şimdi bu hukukun koymuş olduğu cezaları ve suç saydığı eylemleri görelim.

A) Hakk Allah'a giren değişmez cezalar (Hadd, Hudud): Hadd lûgatte "Menetme, engel olma" anlamina gelir. Allah'n yapılmamasinı emrettiği eylemleri kişilerin işlemesine engel olduğu ve işliyenleri tekrar işlemekten menettiği için Hakk Allah'a giren cezalara da bu isim verilmiştir. Beş Hadd vardır: Zina, zina iftirası (= Kazf), șarap içme (şurb-i hamr), hrrszzllk (sarika veya sirkat), yolkesme (Kat'ül-tarik) (8).

1) Zina: Zina'ya karşı konulmuş olan cezanın gayesi đ̇slâm camiasında "Neseb» doğruluğunu temin etmektir. Buridan ötürü ancak nesebi ilg̣ilendiren haram bir eylem işlenmişse zina haddi uygulanır, yoksa yalnız öpmek, okşamak, yalnızca konuşmak vsr. gibi eylemlere bu ceza uygulanmaz. Zina işliyenlere verilecek olan ceza suçluların

(8) Bazıları sarhoşluk "Hadd ini de ayrıca saydıkları için bazı kitaplarda Hadd'in sayisi altudir. 
"Muhsan» olup olmamalarına göre değişir. Aklı başınđa, ergin, evli ve Müslüman olan her hür kadın veya erkek ise "Muhsan»dır (9). Bir defa evlenmiş olup sonra herhangi bir sebeple evliliğgi sona ermiş olan kimseler de "Muhsan". saylırlar. Bekârlar (10) Müslüman olmiyanlar, kullar, ergin olmıyanlar ve aklı başında olmıyanlar ise "Muhsan" saylimazlar.

Muhsan olan erkek veya kadının işledikleri zina suçunun cezası "Recm» yani taşlanarak öldürülmektir. Muhsan olmyanlara ise yüzer değenek vurulur. Kullar bu cezanın yarısına çarptırılıriar. Kur'anda zina için tâyin edilmiş olan ceza yalnız yüz değenektir ve suçlunun Muhsan olup olmamasina göre bir ayrım yaplmamıs tır (11). Muhsan olanlara verilen "Recm» cezası Islâm hukukuna sonradan Yahudî hukukunun tesiriyle girmiş olmalidir (12). Peygamber'in recm cezasını uygulamış olduğu hakkında nakledilen hâdislerin de doğru olduğu kesin olarak tesbit edilmemiştir.

Zina işliyenlerin cezalandırılabilmeleri için suçluların bilerek ve istiyerek ve hiç bir basınç altında kalmadan suçu işlemiş olmaları ve işledikleri eylemin suç olduğunu bilmiş bundan şüphe etmemiş olmaları gerekir. Çünkü şüphe halinde ceza uygulanamaz: Msl. oğlunun malını kullanmak hakkı Islâm hukuku tarafından kendine tanınmış olan baba bu hakka dayanarak oğlunun cariyesi ile cinsî münasebette bulunmuşsa bu durumda bu babaya zina cezası uygulanmaz, çünkü baba böyle bir hakkı plduğunu sanmıştır. Babasınin kabını kacağını, eşyasını kullanan bir oğul cariyesi ile de cinsî münasebette bulunabileceğini sanar ve bu yolda hareket ederse oğul da cezalandurlmaz. Birbirleriyle evlenmeleri yasak nian bir kadin ve -erkek de bu yasağı bilmiyerek birbirleriyle evlenmişlerse bunlar da zinadan ötürü cezalandurlmazlar, zira bunlar sahik bir evlenme ile bağlı olduklarını sanmışlardır: Bunun gibi bir erkek kendisiyle zina işlediği kadının, karısı olduğunu iddia ederse, iddiasını ispat edemese bile cezalandirımaz, zira o kadının kendi karısı olduğunu sanmiştır. Buna karşllık zinadan sonra evlenen kimseler cezadan kurtulamazlar. Suçlulardan biri bir şüphe tesiriyle suçu işlediğini iddia ederse diğer suçlu da cezadan kurtulur.

. (9) İmam Şafî̀'ye göre Muhsan sayılmak için Müstüman olmak gerekmez.

(10) Bk. Krosmarik, a. g. e., S. 102 de herhalde yanlışlıkla dulları da Muhsian olmryanlar arasında saymış olacak.

(11) Bk. Kur'an, XXIV. Sure. 2 Ayet.

(12) Tevrat, İkileme (Tesniye) XXII. $21-24$. 
Diștan gelen basınç (tehdit, cebir gibi) altında suçu işlemiş olduklarını iddia eden suçlular iddialarını ispat etmek ödevindedirler.

İslâm hukukunun uygulanamadığı bir ülkede işlenmiş olan zina suçu da cezalandırilmaz.

Zina suçu ya ikrar ile yahut ta tanıklarla sabit olur. Suçun tanıkla ispat edilebilmesi için dört erkek tanığın aynı zamanda ve birlikte, zina suçuna gözleriyle gördükleri hakkında açıç̧a tanıklıkta bulunmaları gerektir. Ayrıca yargıcın tanıklara ayrı ayrı, gördükleri eylemin mahiyetini, şeklini, nerede ve ne zaman kiminle işlendiğini sorması gerekir, çünkü tanıkların gördükleri eylem zinadan başka bir şey olabilir, İslâm ülkesinin dışında işlenmiş olabilir, işlendikten sonra zamanaşımına uğramış olabilir ve kadın erkeğin karısı veya cariyesi olabilir veya erkek bundan șïphe etmiş bulunabilir (13).

Tanıklardan biri görüldüğü gibi tankklıkta bulunmazsa veya tanıkların sayısı dörtten aşağı olursa yalnız sanıkiar beraet etmezler, tanıklar zina iftirasindan dolayı cezalandırılırlar. Bu dört tanıktan birisi zinayla santk bulunan kadinm kocası da olabilir.

Tanıklarm sözleriyle suç sabit görülüp ceza uygulandıktan sonra tankklardan birisinin sözlerinin hukukî bir sebepten ötürü yerinde veya mutaber olmadığı anlaşılırsa suçlunun Muhsan olup olmamasına göre başka başka sonuçlar doğar: suçlu recm cezasına çarptırılmışsa veresesi Beytülmal'den Diyet istiyebilir. Suçlu değenek cezasına çarptırılmışsa bir şey istiyemez. Recm cezası yerine getirildikten sonra tanıklardan birisi sözlerini geri alırsa "Kazf" cezasına çarptırılır ve ölenin Diyetinin 1/4 ini ödemek mecburiyetinde kalır. Recm cezası uygulanmadan önce tanılardan birisi sözlerini geri alırsa recm cezası infaz edilmez buna karşllık tanıklarin dördü de "Kazf» cezası ile karşılaşırlar. Tanıklar dörtten artık idiyse, dörtten artık tanıkların sözlerini geri almaları hiç bir hukukî sonuç doğurmaz.

Zina suçu sabit görülüp yargıç tarafından Recm cezasına hükmedilir edilmez cezanın infazı gerekir: bunun için hülkümlü bir meydana götürülür, taşlyyacak olanlar da camideymiş gibi sıra olurlar. Hükümlü kadınsa yarı beline kadar toprağa gömülür. Gebe kadınlar doğurduktan ve lohusalıktan kalktıktan sonra recmedilirler. Doğan çocuğa bakacak kimse yoksa ceza, çocuğun anasına ihtiyacı kalmıyacağı zamana kadar geri bırakılır. İlk taşları tanıklar atmak mecburiyetindedirler, onlardan sonra hükmü veren yargı̣ ondan sonra da

(I3) Bk. Mevkufat. I, S. 361 ve öt. 
halk taşları atarlar. Halktan kimse taş atmak istemezse Beytülmal'den ödenmek üzere bu işi için ücretle adam tutulur. Tanıklar suçluyu taşlamaktan çekinirler veya infaz yerine gelmezlerse veya bunlardan biri ölmüş bulunursa ceza uygulanmaz, çünkü tanıkların, ceza uygulamncıya kadar sözlerini geri almalari mümkündür. Recm cezası infaz edildikten sonra suçlu bütün diğer Müslümanlar gibi gömülür.

Değenek cezasına hükmedilmiş ise erkek suçlular iç çamaşırlarından başka elbiselerini çıkarırlar ve ceza ayakta infaz edilir. Kafa, yüz gibi kolay incinir yerler hariç vücudun türlü yerlerine vurulur. Darbeler ne çok şiddetli ne de çok hafif olmamalidır. Kırbaçla vuruluyorsa kırbaç dügüumsüz olmalıdır. Yüz darbeden ellisi bir günde diğer ellisi de ertesi gün vurulmalıdır. Kadınlar kürk gibi darbelerin bütün kuvvetini kesen elbiselerden başka elbiselerini çıkarmazlar ve bunlara ceza otururken uygulanir.

Zina suçu ikrar ile de sabit olabilir. Ancak tanılarla ispata eşit sonuçlar doğurması için hem erkeğin hem kadının ikrar etmesi gerekir. Bunlardan yalnız birinin ikrarda bulunması ikrar edenin bile cezaya çarpılmạsı sonucunu doğurur. Yalnız ergin ve akh başında olanların ikrarları muteberdir; sarhoşların ikrarı muteber sayılmaz. Tanıkla ispatta dört erkek tanık gerekmesine karşillk suçlunun da ayrı ayrı duruşmalarda suçunu dört kere ikrar etmesi gerekir. Her ikrarda yargıç suçluya, ikrarın muteber olması için dört defa tekrarlanması icap ettiğini söyler. Buna rağmen suçlu dört kere ikrar ederse, tanklara sorulan sorular suçluya da sorulur ve ancak bunlara da tatmin edici cevap aldıktan sonra yargı̣ cezaya hükmeder. Yargıcın suçluya suçu ne zaman işlediğini sorması icap etmez, zira zamanaşımı yargıcı yalnız tanıkları dinlemekten meneder, ikrara tesir etmez.

Suçlu her zaman ikrarından geri dönebilir, hattâ fikahçılar, bunu suçluya hatırlatmasım yargıca tavsiye bile ederler. Suçlu cezanın infazından önce veya infazı sırasında bile ikramndan dönerse serbest bırakılır. Cezanın infazından önce kaçan suçlu da artık kovuşturulmaz, çünkü suçlunun kaçması ikrarını geri almış olduğuna karine teşkil eder. İkrar da geri almakla birdir.

İkrar sonucunda recm'e hüküm giymiş olan şuçluya ilk tașı yar* gic atar ondan sonra halk atar.

Zina hakkına bütün bu gördüklerimizden bu suçun çok güç şartlar altında sabit olabileceği ve cezaya hükmedip uygulamanın hemen hemen imkânsız olduğu anlaşılmaktadır. Gerçekten zina'dan ötürü 
cezaya hükmedildiğini, hele recm'e hükmedildiğini tarih kitapłarı çok nadir olarak kaydetmektedirler.

2) Kazf: Zina iftirasinda bulunan kimselerin cezalandırilması keyfiyeti XXIV. Surenin 4. Ayetine dayanmaktadır: "Dört tanık göstermeksizin namuslu bir kadın zina ile suçlandıranlara seksen değenek vurulacaktır». Bu ayete göre yalnız kadınlara zina iftirasında bulunanlarin cezalandırlmasi gerekmekteyse de yorumcular bu ayeti ,erkeklere karşı aynı suçu işliyenleri de aynı ceza ile cezalandırmak gerekir diye yorumlamışlardır (14). Fikıhçilara göre her kim "Muhsan» (15) olan bir kadına veya erkeğe açlkça (sarih), veya, kızgmlık halindeyse, iki anlamlı veya kapalı sözlerle zina isnat ederse ve bu sözlerini, zina suçunda gördüğümüz üzere, dört erkek tanikla ispat edemezse zina iftirasında bulunmuş sayılır ve suçlu hürse Kur'an'da yazılı olan seksen değeneğe (celde), kulsa kırk değeneğe hüküm giyer. Müslüman olmiyanlara karşı ișlenmiş olan kazf suçların ise yargı̧̧ münasip bir şekilde Tazir'le cezalandırır.

Birçok fıkıhçılara göre bir kimsenin arkasından da ona zina isnat etmek kazf sayılırsa da esas itibariyle kazf suçunun yüze karş̧ı işlenmiş olması gerekir, yoksa bir kimsenin arkasından ona zina isnat edecek şekilde konuşmak kötü dedikodu sınırlarını aşmaz. Böylece "Muhsan» olan bir kadının yüzüne karş̧ zina işlemiş olduğunu söyliyen kimse kazf suçu işlemiş sayıldığı halde aynı kimsenin arkasmdan aynı sözü söyliyen kimse aynı suçu işlemiş sayıImaz. Bir kimsenin Kazf'den ötürü cezalandrrılabilmesi için ayrıea, isnat ettiği zina öyle bir zina olmalıdrr ki, sözünü ispat edebildiği takdirde kar\$̧ taraf hakikaten zina suçunun cezasına çarptrrilabilsin, yani isnat edilen zina şüphe vsr. den arkk olmalıdır.

Yukarda Kazf suçunun daha çok Hakk Allah'ı ihlâl etmekle beraber Hakk Âdemi'yi de ihlâl ettiğini söylemiştik, bundan ötürü suçlunun kovușturulması bakımından zina ile Kazf suçlarının farkı vardır: Kazf'ten ötürü bir kimsenin yargılanabilmesi için Kazf'e uğramış olan kimsenin şikâyeti gerekir. İmam Şafîî̀ye göre Kazf'ten ötürü suçlunun cezalandırılmasını istemek hakkı Kazf'e uğrayan kimse öldüğü takdirde mirasçılarına geçer. Ebu Hünife ise. Kazf suçu dạha çok Hakk Allah'ı ihlâl etmiş olduğu için, bunu kabul etmez.

(14) Burada Kryas yoluna gidilmemiştir, çünkü yeniden bir Hadd cezası tesbit etmek için Kiyas yolu yetmez. Bk. Krosmarik. a. g. e. S. 316.

(15) Zina iftirasına uğrıyan kimsenin Muhsan sayılması için evli olması gerekmez. 
Hattâ Hanefîler'e göre Kazf'e uğrayan kimse suçlu cezalandurıldığı sırada bile hayatta bulunmalıdır. Zarar görmüş olan kimse suçlunun cezalandırılmasindan önce veya cezalandurldı̆̆ sirada ölürse ceza artık uygulanmaz. Bir ölü Kazf'e uğrarsa o zaman onun Âsebesinin suçlunun cezalandırılmasını istemek hakları vardir. Bu hak mirastan ötürü değildir, zira Msl. murisini öldürmüş olan varisler mirastan mahrum oldukları halde bu hakka sahiptirler.

İki kişi karşllkklı olarak birbirlerine zina isnat etmişlerse, her ikisi de ayrı ayrı cezalandirilır.

Suçlu ile zarar görenin ceza hakkında anlaşmaları, Msl. Kazf.e uğrayazun suçludan tazminat alarak suçluyu affetmesi caiz değillìr. Hattâ tazminat almadan da affetmenin caiz olmac̉ı̆̆ını söyliyenler vardır. Ançak şikâyetçinin şikâyetini geri almasına da bir engel yoktur.

Bir Müslüman'a zina isnat eden Müste'min'e de Kazf Haddi uy- . gulanır. Suçlu Müste'min kanunu bilmediğini ileri süremez, çünkü zina bütün ülkelerde yasaktır, onun için bir kimseye sebepsiz yere zina isnat eden Müste'min de cezalandmmilr. Kazf'de samı suçunu ikrar ederse diğer Hadd'a uyruk suçların aksine olarak ikrarından dönemiyeceğini görmüştük. Suçunu ikrar etmiyen saniğa, yargı६ zina isnadını ispat etmesini söyler. Sanık eğer dört erkek tanıkla veya zina isnat ettiği kimsenin bildiğimiz şekildeki ikrarları ile iddiasını ispat ederse beraet eder ve müddeaaleyh zina suçundan ötürü yargllanır. Aksi takdirde sanık Kazf'ten ötürü cezalandrrłlır. Sanık, duruşma başlayınca, tanıkları hemen dinletebilecek durumda olmalıdır, çünkü tanıkları getirmesi için dava yeri bırakılmaz ve sanık cezaya hüküm giyer. Sanığın bir kefil bırakarak tanıkları bulup getirmesi yolundaki isteğini de yarg1ç yerine getiremez, ancak sanığı hapsederek bașka birisini tanıkları bulup getirmeğe memur eder.

Ceza uygulanirken suçlunun yalnız elbiseleri çıartılır, çamaşırları soyulmaz. Suçluya başka Hadd cezaları da uygulanacaksa - Msl. şarap içtiğinden ötürü - o zaman önce Kazf'den ötürü giymiş olduğu ceza uygulanır, çünkü Kazf'le yalnız Hakk Allah değil biraz da Hakk-i Âdemî ihlâl edilmiştir.. Hakk-i Âdemî'nin ihlâl edilmiş olmasından ötürü verilen cezalar da diğerlerinden önce uygulanır. Diğer cezaların sırasını tâyin etmek, yargıcın takdirine bırakılmıştır: Bir kimse birkaç kişiye birden zina iftirasında bulūnmuşsa o zaman her bir iftira için ayrı ayrı cezaya çarptırılmaz çünkü aynı suçtan ötürü ancak bir defa Hadd cezası uygulanabilir. Bunun gibi bir kim- 
seye zina isnad ettiğinden ötürü cezalandmlmı̧ olar birisi o kimseye tekrar zina isnat etse de artık cezalandirilmaz, zira iftiraya ugrayan kişinin şerefi iftiracının bir kere cezalandırılması ile korunmuştur.

Kazf'ten ötürü cezalandırılmış olan bir kimse bütün hayatınca bir daha tanıklikta bulunamaz (16).

3) Şurb: Hanefiler'e göre her kim şarap veya sarhoş olacak kadar̀ başka içki içerse cezalandırılir (17). Şarap içmek İslâm'm ilk çıktığı zamanlarda yasak edilmemişti. Hattâ Kur'an'in XVI. Suresinin 69. Ayetinde şarabın methedildiği görülmektedir: "Meyveler arasında hurma ve üzüm vardır ki onlardan lâtif yiyecekler ve sarhoş edici içkiler elde edilir, bu düşünen kavim için ibret vericidir». Ancak sarhoşluğun sebep olduğu kötülükkler üzerinedir ki, şarap içmeyi kötülüyen ve yasaklyyan ayetler inmiştir. Bu yolda ilk inen ayet II. Surenin 216. ayetidir: "Şarap ve kumar hakkında senden soracaklardır. Onlara de ki her ikisinin de insanlar için zararı faidesinden çoktur.» Bu ayet de, görüldügü üzere, henüz şarap içme hakkında kesin bir yasak koymamıştır. IV. Surenin 46 Ayeti ise yalnız ibadet sıras̀nnda sarhoşluğu yasakladığına göre, şarap içmenin henüz kesin olarak yasaklanmadığı anlaşılır: "Ey müminler sarhoş olduğunuz vakit namaz kılmayınız, söylediğinizi anlayabilecek hale gelmenizi bekleyinizm. En son şarap içmeyi kesin olarak yasaklıyan ayet V. Surenin 92. ayetidir: “Ey müminler șarap, kumar, putlar ve ok ile fala bakmak șeytanın icadettiği işlerdir. Bunlardan kaçınınız, felâh bulưsunuz». Bu ayetle şarap içmek yasaklanmış olduğu halde Zina ve Kazf'de olduğu gibi buna karşı konulmuş olan ceza Kur'an'da tesbit edilmemistir. Şarap içmenin haram olduğu hakkında birçok Hadisler nakledildiŏ halde, bunun cezasını seksen değenek olarak tâyin eden bir hadis nakledilmemiştir. Yalnız Peygamber'in ve Ebubekir'in şarap içenleri kırk değenek ile cezalandırdıkları hakkında Hadisler nakledilmiştir. Nihayet şarap içmenin cezasının seksen deḡenek nlarak tesbiti Ömer zamaninda olmus ve bunu bütün mezhepler kabul etmişlerdir, yalnız Şî̀ler Peygamber'e uyarak kırk değenekte israr etmişlerdir (18).

Şu halde kim şarap içerse - isterse bir damla olsun - bir suç işlemiş sayılır ve yakalandığı zaman ağzı hâlâ șarap kokuyorsa ce-

(16) Bk. XXIV. Sure. 5. Ayet: «Ve öylelerin tanıklıklarını ebeden kabul etmiyeceksiniz».

(17) Hanefi Mezhebinden başka Mezheplerde ispittolu içkilerle şarap arasında bir ayrım yapılmamıştır.

(18) Bk. Handwörterbuch des İslâm. S. 301. Satir. 2. 
zalandırılır. Cezanın verilebilmesi için ayrıca iki erkeğin tanıklı̆̆ı veya sanı̆ın ayıken suçunu ikrar.temiş olması gerekir (19). Saniktan şarap kokusu gelmiyorsa ne tanikla ne de ikrar ile cezalandirılmasına hükmedilemez, zira şarap lçme de kokunun kaybolması ile sự zamanaşımına uğramış sayılır.

Şaraptan başka bir içkiden sarhoş olacak kadar çok içen kimseler de aynı şekilde cezalandırılurlar. Ebu Hanife'ye göre sarhoş, erkekten kadın, gökten yeri ayırmıyan kimsedir. İmameyn'e göre ise konuşmasi makul olmıyan ve sözlerini birbirine kariştıran kimse sarhoştur. Aneak burada kokunun geçmesiyle değil sarhoșluğun geçmesiyle suç zamanaşimına uğramış sayılır $(20)$.

Cezaya hükmetmeden önce suçlunun istiyerek mi yoksa zorla mi içtiğini, ne zaman içtiğini ve nerede içtiğini yargıcın sorması gerekir. Çünkü suçlu şarabı veya diğer içkiyi zorla içmiş olabilir; içtikten sonra zamanaşımına uğramış olabilir (21) ve nihayet suçlu suçu İslâm ülkesi dışınđa işlemiş olabilìr.

Ceza, suçlu kendine geldikten sonra ve zina da olduğu gibi uygulanir.

İslâm ülkesine yeni yerleşmiş olan Müslümanlar veya İslâmı yeni kabul etmiş olan kimseler şarap içmenin suç olduğunu bilmediklerini ileri sürerek cezadan kurtulabilírler. Müslüman olmiyan kimseler ise hiçbir sưretle şarap̀ veya başka içkiler içtiklerinden ötürü cezalandırılmazlar.

4) Sirkat, Sarika (Hursizlık): İslầm ceza hukukunda hursızlık, küçük hırsızlık (= Sirkat al - sugra) ve büyük hırsızlık (= Sirkat al - kübra) diye ikiye ayrlmaktadır. Biz ilkönce asıl hirsizlık olan küçük hursızlığı göreceğiz.

Hirsızlık yapanlar da Hakk Allah'ı. ihlâl etmis olurlar ve bundan ötürü Kur'an'ın V. Suresinin 42. ayetinde belirtilmiş olan Hadd cezası ile cezalandurılırlar: "Kadın ve erkek Sârik'in yaptığına ceza olarak ellerini kesiniz onlara. Allah'in verdiği ceza budur». $\mathrm{Ne} b \mathrm{bu}_{\mathrm{r}}$ Ayet'de ne de başka bir ayet'de hirsızlığn ne olduğu tarif edilmemiştir. Sonradan fikıhçılar daha çok Hadislere dayanarak ve kıyasa baș vurarak hırsızlığı şöyle târif etmişlerdir: kim kendisinin olmıyan

(19) Ebu Yusuf'a göre iki kere ikrar etmesi gerekir. Bk. Mevkufat, I. 369.

(20) Bk. Mevkufat, I. 369.

(21) Ebu Hanife ve Ebu Yusuf'a göre suçun işlendiğł yer ile Mahkeme birbirinden uzak değilse kokunun kaybolmasiyla suç zamanaşımına uğrar. Imam Muharnmed'e göre burda da zamanașum 1 aydur. Bk. Mevkufat, I. 369. 
ve başkasının muhafazası altında bulunan ve değeri 10 gümüş̧ dirhemi asan bir malı gizlice alırsa hursızlık etmis olur.

Bu tariften ötürü hırsızhk "gasb» ile karıştırılmamak gerektir. Çünkü Gasb'da gizlilik unsuru olmadığı gibi Gasb'in konusu bir hak da olabilir. Meselâ kendisinin olmiyan bir evi, sahibinin izni olmaksızın, kendi menfaatini sağlyyacak şekilde kiraya veren bir kimse bu hakkı gasbetmiş olur. Hırsızlık için İslâm hukuku ceza tâyin etmiş olduğu halde Gasb için bir ceza tâyin etmemiştir; gasbeden kimse yalnız öbür dünyada cezalandırılır, bundan başka gasbettiği şeyi sahibine geri vermek veya değerini ödemek mecburiyetindedir. Gasberen zilyed olduğu halde üçüncü kişilere karşı da korunmaz.

Hırsızlıkla dolandırıcılığı da birbirine karıștırmamak gerekmektedir; çünkü dolandırıcılıkla suçlu bir malı hile kullanarak sahibinin rızası ile elde etmektedir. Dolandırıcılık için İslâm Ceza hukukunda belli bir ceza yoktur. Bu suç Tazir ile cezalandrrılır.

Hırsızlığın tarifinden de anlaşılacağı üzere evlemin gizlice işlenmiş olması suçun en önemli unsurlarından birisidir. Bundan başka, bir kimsenin hırsız sayılabilmesi için, çalınmış olan malın muhafaza (Hirz) altında bulunmuş olması şarttır. Bundan ötürü gereken şekilde muhafaza edilmiyen bị malın alınmış olması hursızlık sayxlmaz. Hangi malların muhafaza altında saylacağ̀ ise duruma göre değişmektedir: malın sahibi, sahibinin kulu veya vekili malı bizzat gözlerinin altında tutuyorlarsa veya malı muhafaza edilebileceği bir yere koymuşlarsa o mal muhafaza altında (Muhraz) sayllr. Bundan ötürì iki türlü muhafaza vardur: muhafiz ile muhafaza (Ha$f_{1 z}$ ile muhraz) ve yer ile muhafaza (Mekân ile muhraz). Yer ile muhafazā muhafız ile muhafazadan üstün tutulur. Mal çöl gibi, kır gibi bir yerde veya insanların mal saklıyamryacakları cami gibi bir bina içinde ise yer bakımından muhafaza altında sayılmaz, bu gibi durumlarda malı, sahibinin veya vekilinin göz alinda tutması gerekir. Buna karşllık kapalı bir yerde bulunan bir malı sadece arasıra gözetmek malın muhafaza altında sayılması için yeter. Çölde veya camide uyuyan bir kimse elbiselerinin üstünde uyuyorsa veya mallarını başının altına koymuşsa bu mallar muhafaza altında sayılir; ancak o kimse uykuda kayarak veya yuvarlanarak mallarından ayrılmıssa mallar artık muhafaza altında sayılmazlar.

Ahrr hayvanlarm muhafaza edilmesi için uygun bir yerdir, fakat ev eşyası için değildir. Onun için ahırdan Ms! bir tencere çalmıș olan kimse hırsızlık yapmış sayılmaz. Bunun gibi bir evin av- 
lusu eşyanın saklanması için uygun bir yer olduğu haldẹ orada bulunan para ve mücevherler muhafaza altinda sayılmazlar.

Bir malın gereken sekilde muhafaza altında saylabilmesi için o malın sahibinin veya bekçisinin, hirsizın hücumunu kuvvetle veya başkalarım çağırmak suretiyle savacak durumda olmaları gerekir. Bunun için şehirden uzakta bulunan bir ev, içinde uyumiyan ve kuvvetli bir bekçi bulunduğu müddetçe uygun bir muhafaza yeri sayılabilir. Evin kapısının kapalı veya açık olmasının buna hiçbir tesiri yoktur. Buna karşıllk şehirdeki bir evin kapısı kapalı olur ve içinde bir bekçi bulunursa, bekçi uyusa bile ev uygun bir muhafaza yeri sayıhr. Ancak böyle bir evin kapısı açık olduğu halde bekçi de uyuyorsa ev uygun muhafaza yeri olmaktan çıkar.

Islâm Ceza hukukuna göre hirsızlığın cezası el, ayak kesme ve hapistir. Kur'an'da yalnız el kesme yazllı olduğu halde sonradan ayak kesme ve hapis cezaları buna eklenmiştir. Henefiller'e göre hirsızın birinci hırsızlıkta sağ eli, ikincide sol ayağı kesilir, üçüncüde ise tövbe edinciye kadar hapsedilir (22). El bilekten kesilir, ancak ancak suçlunun bir eli daha önce kesilmişse veya çolaksa veya diğer elin başparmağı veya iki parmağ daha önce kesilmişse eli de kesilmez. Yara çabuk iyileşemiyeceği ve suçlınun hayatı tehlikeye gireceği için ceza çok sıcak veya çok soguk havalarda uygulanmaz.

Hursızlığın ispatı için ya iki erkek tanığın tanıklığı veya suçlunun suçunu ikrar etmiş olması gerekmektedir. Bütün Hakk Allah'a giren suçlarda olduğu gibi ikrardan dönülebilir ve cezanın infazmdan önce suçlunun kaçması ikramnı geri aldığına karine sayılır. Yargıç tanıklara suçlunun neyi çaldığını, nerde ve ne zaman çaldığinı, çaldiğı malın değerinin ne olduğunu ve kimin malını çaldığmı sormakla ödevlidir. Suçu, suçlu ikrar ediyorsa yargı̨̧ aynı soruları. ona sorar, yalnız burada ne zaman çaldığını sorması gerekmez, çünkü suçlu suçunu ikrar ederse hırsızlikta zamanașımı bahse konu olamaz (23).

Muhafaza edilemiyen veya çok miktarda bulunduğu için muhafazaya değmiyen malları çaldığı için hırsız Hadd cezası ile karşılaşmaz. Bu gibi mallara "Tâfih" denir. Bunlar kuru odun, ot, çayır, kamış, balkılar, av hayvanları, kireç vsr. gibi şeylerdir. Hanefîler'e

(22) İmam Safî̀’ye göre ikinci defada sol eli dördüncü defada ise sa ayağı kesilir, Bk. Mevkufat, I. 378.

(23) Bk. Kresmarik. a. g. e. S. 328. 
göre süt, et, meyva gibi çabuk bozulan şeylerin çalınmasından ötürü de suçunun eli kesilmez.

Kari kocasınm, koca da karismm mallarını çalsalar, bu İslàm ceza hukukuna göre hırsızlık sayılmaz. Çünkü ikisinin malını iyice birbirinden ayırmak mümkün değildir. Bunun gibi kul efendisinin veya efendisinin karısının, misafir ev sahibinin malını çalsalar, bu suçlar da hırsızlık sayılmaz. Çalınan mal bir yabancinın malı da olsa yakın hısımdan çalmak hırsızlık değildir. Halbuki bir yabancının muhafazası altında bulunan hısım malını çalan hırsızın eli kesilir.

Ekonomik hayatta değeri olmıyan bir eşyanın çalmmasından ötürü - bu eşyanm ayrıca büyük bir değeri de olsa - de hırsız cezalandırılmaz. Meselâ sarhoş edici içkiler bu türlü eşyadan sayılırlar. Ancak bu gibi eşyanın bir Müslüman'dan çalınmiş olmasi gerekir, bir gayrimüslim'den çalınırsa eli kesilir, çünkỉ Gayrimüslimler için o eşyanın ekonomik değeri de vardır. Değerli maddelerden ya'pılmış haçlar, Kur'an nushaları, oyuncaklar ve hür cocuklar da bunlardan sayilır.

Emniyeti kötü kullanmaktan ötürü de el kesilmez, çünkü burada hrrsızlık suçunun unsurları tam değildir. Ölülerin yüzüklerinin veya altın dişlerinin çalınması da hırsızlık değildir, çünkü mezarlarda bulunan şeyler muhafaza altında sayılmazlar.

Calınan malın bir başkasının malı olması, hırsızlık suçunun en önemli unsurlarından biri olduğu için çalınan malda hırsızın en küçük bir payı bile olsa işlenmiş olan eylem hırsızlık sayılmaz. Bunun için henüz paylaşlımamıs olan ganimet veya Devlete ait olan malları çalmak Hadd cezası ile cezalandrrılmazlar, çünkü henüz paylaşlmamıs olan ganimette sefere katılmış olan kimsenin, kamu malında da devleti teşkil eden bütün kişilerin küçük de olsa bir payı vardır. $\mathrm{Bu}$ husus edebiyatımızda da yankılar uyandırmaktan geri kalmamıştır: Sünbülzade Vehbi (Ölm. 1224/1809) nin Suhen kasidesinde söylemiş olduğu meşhur

"Sirkat-i şi'r edene kat-i zeban lâzımdır

Böyledir şer'-i belâkette fetava-i suhen"

beytine karşllı Şeyh Galib (1171/1757 - 1213/1798) Hüsn-i Âșk'ında

«Esrarin Mesnevî'den aldım.

Çaldımsa da mirî malı çaldım.

beytỉni söylemiş ve böylece Mesnevî gibi bir eserin yalnız yaza- 
rına değil kamuya ait olduğunu ve ondan mıralar veya fikirler çalmanm - Sünbülzadenin dediği gibi şiir hırsızlığında İslâm hukukuna uyulsa bile - dil kesmekle cezalandırlamıacağını anlatmak istemiştir. Burada şunu da eklemek isteriz ki, İslâm hukukunda kamu malını ne çalmak ne de ihtilâs etmek mubah değildir yalnız yukarda söylediğimiz sebepten ötürü Hadd cezası ile cezalandirılmaz. Bunun gibi bir borçludan alacaklısının bir mal çalması da, borç henüz muaccel olmasa ve çalınạn malın değeri borcun değerini aşsa bile Hadd cezası ile cezalandirılmaz.

Hırsız çaldı̌̆ı şeyi ancak alıp götürdükten sonradır ki suç tamamlanmış sayılır. Bundan ötürü bir malı çalıp da malı bulunduğu yerden götürmiyen veya çaldığı malı dışarda bulunan orțğı aracıyla uzaklaştıran hırsızin da eli kesilmez. Ancak malı bulunduğu yerden dışarı atmış ve sonra uzaklaştırmışsa o zaman eli kesilir.

Hursız ancak zarar gören yanın isteği ile cezalandırılabilir. Yalnız, yargıç hükmünü verdikten sonra davacı suçluyu affettiğini bildirerek cezanin uygulanmasının önüne geçemez; çünkü hırsızlıkla Hakk Allah ihlàl edilmiştir. Buna karşllık zarar gören yan çalınmış olan malın hırsızın mah olduğunu söyliyerek cezanın infazına engel olabilir.

Dava başlamadan önce hirsıı çalınan malı geri verirse veya bu mal hukukî bir yoldan (Msl. Hibe gibi) kendi malı olursa cezadan kurtulur. Çalınan malın kendi malı olduğunu sanan hırsız bu sanısının doğruluğuna yargıcı kandırabilirse cezalandırılmaz, çünkü Zina'da gördügüumüz üzere şüphe ile Hadd sakıt olur. Hattâ çaldığı malın kendisinin olduğunu iddia eden hırsız bu iddiasını ispat bile edemese gene cezalandirlmaz (24).

Birlikte hirsızlık edenler ya hep birlikte hüküm giyerler veya hepsi beraat ederler. Bu suretle birlikte hırsızhk etmiş olan iki hrrsızdan her ikisi de suçlarını ikrar etseler, fakat bunlardan birisi çaldıkları malın kendisine ait olduğunu sandığını söylese her iki suçlu da beraat ederler. Birlikte hrrsıluk edenlerin cezalandirlabilmeleri için çaldıkları eşya hırsızlar arasında paylaşıldığı zaman her birine en aşağı on gümüş dirhem değerinde eşya düşmelidir.

Hırsız Hadd cezasına hüküm giyerse ve eli kesilirse ayrı çaldığı için tazminat vermek mecburiyetinde değildir, çalınan mal duruyorsa o sahibine geri verilir. Ónce çalmış olduğu bir maldan ötürü eli kesilmiş olan hırsız, aynı malı tekrar çalacak olursa bir defa daha

(24) Bk. Kresmarik. a. g. e. S. 331. 
cezaya çaptırımaz. Çalınan malın değeri araştırılırken bu malın hem çalındığı hem de cezanın uygulandığı sıradaki değerini tesbit etmek gerekir: çalınan mal çalındığı gün on gümüş dirhem değerinde değildiyse o zaman bu hırsızlıktan ötürü dava açlamaz; eğer çalındığ 1 zamaii on gümüs dirhem veya daha artık değerde olan malın değeri, cezanın uygulanacağı zaman, on gümüş dirhemden aşağı düşmüssse bu takdirde ceza yerine getirilmez.

5) Yolkesicilik (= Kat' ül-tarik): İslâm ceza hukukunda yolkesicilik, yukarda da görmüş olduğumuz gibi hırsızhı̆ın daha ağır bir cezaya uyruk tutulan bir şekli sayılmaktadır. Gerçekten hrrsızlikta aranan unsurlar burada da bulunmak gerektir; şöyle ki, yolkesenin de aldığı mal on gümüş dirhemi geçmelidir; bu mal muhafaza altmda olmalı (Muhraz) ve gizlice alınmıs olmalıdır. Yolkesicilikte bu unsurlarm hepsi bulunamıacağı için bunlarır varlığı yapintı yolundan gidilerek kabul edilir; çünkü yoldaki bir yolcuyu durdurup cebirle mallarinı almak demek olan yolkesicilikte gizlilik unsuru bulunamaz. Bunun için şöyle düşünme yolu tutulmuştur: bütün uyruklarının ve bilhassa yolcuların can ve mallarmm emniyetini temin etmek İslâm Devleti reisinin ve adamlarının vazifesidir. Yolkesenler Devlet reisinin veya onun tâyin etmiş olduğu zabita memurlarının haberi olmadan suçlarını işledikleri için suçlarını gizlice işlemiş sayılırlar. Bundan ötürü devlet kuvvetlerine karşı gelecek şekilde adam öldüren ve soyanlar yolkesici değil âsi sayllirlar (25).

Ayrıca İslâm ülkesi dışında işlenen yolkesicilik suçlarına ve İslâm Devleti uyruklarından başkalarına karşı işlenen veya İslâm Devletine uyruk olmiyanlar tarafmdan işlenmiş olan yolkesicilik suçlarına ceza uygulanmaz, çünkü İslâm ülkesi dışında işlenen eylemlere İslâm hukuku uygulanamıyacağı gibi İslâm Devleti tarafindan korunmıyan kimselere karşı işlenen veya eylemleri İslâm Devleti tarafindan kontrol edilemiyen kimler tarafından ișlenmiş olan suçlara da İslâm hukuku uygulanamaz.

Yolkesiciliğe verilmesi gereken ceza Kur'an'da V. Suresinin 37. Ayetinde tâyin edilmiştir. Bu ceza türlü türlüdür: Yolkesen yalnız mal alıp götürmüsse sağ eli ve sol ayağı kesilir. Tabiidir ki alınan malın değeri 10 gümüs dirhemi aşmalı, yolkesenler birden çok ise suçluların sayısı kere 10 gümüss dirhemi aşmalıdır. Yolkesen mal almaksızın yalnız adam öldürmüşse kendisi de öldürülür. Burada verilen ölüm cezası Hadd olduğu için öldürülen kimsenin veresesi

(25) Bk. Kresmarik. a. g. e. S. 333. 
suçluyu affedemez veya onunla Kısas yerine Diyet vermek yolunda bir anlaşma yapamaz.

Yolkesen hem mal almuş hem de adam öldürmüşse verilecek ceza hakkında tartışma vardır: bazları suçlunun önce sağ eli ve sol ayağının kesilmesinin sonra da öldürülmesinin gerektiğini söylerler. Bazlları ise suçlunun salbedilmesi gerektiğini. ileri sürerler, gerçekten Kur'an'da "Katl ve salb edersiniz" diye yazılıdır. Suçlu ya öldürüldükten sonra salbedilir yahut ta öldürülmeden salbedilir ve karnı bir mızrak ile deşilir. Ǘç gün salipte kaldıktan sonra indirilir ve gömecek olanlara teslim edilir.

Yolkesen ne mal almış ne de adam öldürmemişse gene cezasız kalmaz, bu gibiler sürgüne gönderilir veya nefislerini düzeltinciye kadar hapsedilirler. Bu gibi suçlular yolkesiciliḡe teşebbüs etmiş oldukları için değil yolların emniyetini bozdukları için cezalandırılırlar; çünkü İslâm ceza hukukunda teşebbüs cezalan̈dırılmaz.

Yolkesici birden artık ise ve bunlar birlikte yolkesmişlerse hepsi birden cezalandırılırlar, hattâ bunların içinden yalnız birisi adam öldürmüş veya mal almış veya her iki eylemi birden işlemiş olsa bütün suçlular bu suçlunun çarptırılacağı cezaya çarptırılırlar yani yolkesicilerden yalnız birisi adam öldürmüss olsa diğerleri de ölüm cezasma çarptırılırlar. Yalnız mal almaktan ötürï hepsinin sağ el ve' sol ayaklarmın kesilebilmesi için, yukarda da söylediğimiz gibi, alınmış olan malın değeri suçluların adedi kere on gümüş dirhem değerinde olmalı veya bu değeri aşmalıdır.

Yolkesen birisinin malımı almış ve onu yaralamıssa, yol kesip mal aldığı için Hakk Allah'ı ve adam yaraladığı için de Hakk'i Âdemî̀yi ihlâl etmiş olur. Böyle bir suçlu yolkesicilikten ötürü cezalandırılırsa artık adam yaralamış olmaktan ötürü cezalandırılmaz, çünkü Hadd ile Hakk-i Âdemî düşer (26). Eğger herhangi bir sebepten ötürü suçluya Hadd cezası uygulanamazsa o zaman yaralamadan ötürü cezalandrrllabilir. Adam öldürüp de yakalanniadan önce tövbe eden yolkesiciye de V. Surenin 38. ayetine uyularak Hadd cezası verilemez, ancak bu gibi suçlular KIsas'a uyruk tutulurlar.

Yolkesici çetesi içinde ergin veya aklı başında olmıyan bir kimse bulunursa, bunlar cezalandırlamıyacağı için diğer suçlular da cezalandırılmazlar, çünkü çete üyeleri işledikleri suçtan ötürü hep birlikte sorumludurlar, bunlarm içinden birisine Hadd uygulanması gerekince nasıl diğerlerine de ayn Hadd uygulanıyorsa, birisine uy-

(26) Bk. Mevkufat, I, 381.

Hukuk Fakültesi Mecmuası 10 
gulanmadığı takdirđe hiç birine uygulanmaz. Yolkesicilerden birisi hücuma uğrıyan kişilerden birisinin yakın akrabası (= zu rahim mahram) ise, hrrsızlıkta olduğu gibi burada da Hadd cezası uygulanamaz.

Yolda bulunan bir kafilenin bazı yolcuları, soymak kasdiyle diğer yolculara hücum etseler ve adam öldürseler, bu eylem de yankesicilik saylmaz ve Hadd cezasına uyruk tutulmaz, çünkü kafile bir ev gibidir ve hücum edenler kafilenin içinde olduklarından, oraya girmiş sayılmazlar.

Yolkesiciler suçu gece işlemişlerşe gene Hadd cezası ile karşılaşmazlar, çünkü zabıta kuvvetleri geceleri yolların emniyetini temin edemezler.

Yolkesiciler bir şehirde veya iki birbirine yakın şehir arasında suçların işlemişlerse gene Hadd cezası ile karşılaşmazlar çünkü bu gibi yerlere yardım yetişmesi imkânı vardır. Ancak bir şehirde suç işliyen yolkesiciler silâhlı idiyseler Hadd ile cezalandırılırlar. Ellerinde tas veya sopa bulunan yolkesiciler ise silâhlı sayılırlar.

Bu gibi Hadd cezasının uygulanmadığı durumlarda yaralanmış olan yolcular veya öldürülmüs olan yolcuların veresesi suçluyu kovuşturarak Kisas cezasının uygulanmasını veya Diyet alınmasını istiyebilirler, isterlerse de suçluyu affedebilirler.

Yolkesici de Hursiz gibi, aldığı mal duruyorsa onu sahibine geri vermekle ödevlidir. Eğer bu mal mevcut değilse yolkesici de tazmin ile ödevlendirilemez. Malın kendi kendine yok olmasının veya suçlu tarafından yok edilmiş olmasının burada bir önemi yoktur. Suçlu Hadd cezasına çarptırılmazsa o zaman aldığı malı tazminle ödevlidir. 